\title{
Development of College Archives Management Book
}

\author{
Sri Mutmainnah ${ }^{1}$, Ellys Siregar ${ }^{2}$, Gartima Sitanggang $^{3}$ \\ (mutmainnah.sri@gmail.com, ellyssiregaradp@gmail.com, gartimasitanggang1960@gmail.com)
}

Faculty og Economic and Bussiness, Universitas Negeri Medan

mutmainnah.sri@gmail.com

\begin{abstract}
The amount of unemployment at the university level is due to the low competency which is mastered by graduates. There are no books that can guide students to be able to manage dynamic archives based on the Archive Classification, Archive Retention Schedule. The purpose of this research was carried out to improve the quality of learning through the design of college Archive Management books. Specific Targets in this research resulted: 1) College Archives Management Book, 2) Teaching and Learning Activities Plan based on the Indonesian National Qualification Framework, 3) Archiving learning evaluation instruments, 4) Archiving Learning Media. This research uses a research approach and development (R\&D), the method used is descriptive-exploratory method to identify various symptoms and root of the problems that occur in the study of Archive Management and design of the development of College Archives Management Book.
\end{abstract}

Keyword: Development, Book, Archive

\section{Introduction}

Every institution, whether it is a government, private or non-governmental organization, owns and produces an archive of each of its organizations. The archive serves as the main tool of organizational memory, evidence, material in the decision making process, barometer of organizational activities, legal evidence and as an administrative product [1]. In addition, the increasing need for information from data that has been created by an institute that forces each institute to manage its archives [2]. Thus the importance of archives in an organization, archives management properly will be used as information in doing the work of the organization.

College as one of the government institutions is also not spared from managing archives. Regulation of the Head of the National Archives of the Republic of Indonesia [3], concerning Guidelines for the Implementation of Archives in College. College in Indonesia as a scientific institution plays a strategic role in building the nation's civilization, because it carries out 3 (three) main functions known as the Tri Dharma of college, namely education, research, and community service. In carrying out this function, universities produce archives as recorded information which is an asset of the college and public asset at once that needs to be managed properly as evidence of accountability of college performance that reflects the achievements of the Tri Dharma of college. Therefore, the archives created by colleges have important benefits in the implementation of community, nation and state life.

Dynamic archive management aims to ensure the availability of archives as a material of performance accountability and as valid evidence in the context of carrying out functions and 
tasks [4]. The existence of the archive is not something specifically created, but the archive is created automatically as evidence of the implementation of administrative activities or transactions. The existence of archive reflects a deposition of information on administrative / transaction implementation activities that require archives management to produce information [5].

Furthermore, College Archive Tasks according concerning Archives [6], include: (1) required to carry out static archive management received from work units in college and academic community, (2) managing the academic community's archive in college, (3) managing inactive archives that have a retention of at least 10 years originating from work units and the academic community in college, and (4) archiving guidance in the college concerned.

As part of the national archiving system, colleges organize dynamic and static archiving in their environment. Archives created by universities in any form and style are the nation's collective memory. Dynamic archive management is known as dynamic archive management or records management. There are four archives that must be available and become guidelines for the management of dynamic archives in each institution, both government and private. The four basic instruments for managing archives include: Official Manuscript, Archive Classification, Archive Retention Schedule and Security Archive and Access Archive Classification System. These four basic instruments serve as a factor controlling the practice of each stage in dynamic archive management from the creation, use and maintenance of archives and depreciating of archives [7].

The reality is that currently graduates of Office Administration have not understood and are able to use the four sets of archives above correctly as well as students of Office Administration and Archivists of Medan State University. From the results of the identification of the problems held at the meeting of all Medan state university archivists on January 25, 2019, it was found that all archivists were unable to manage the archives properly. Not understanding and not being able to use four archive devices which must be used in dynamic archive management.

There is no archival book that explains how to manage dynamic archives based on the selected storage system while still referring to TND, KA, JRA and SKKAAD. Meanwhile, the purpose of the preparation of TND, KA, JRA and SKKAAD to ensure the realization of a dynamic archive management system that is integrated from the creation, use, and maintenance to the depreciating of the archive correctly [8].

To improve the mastery of Dynamic Archive Management competencies in students of the Office Study Program and archivists of Medan State University, then it is necessary to design a book on Dynamic Archive Management in college. The innovative thing in the book is to combine the theory and practice of managing dynamic archives by referring to the use of four archive devices (TND, KA, JRA, SKKAAD). Considering there is no Dynamic Archives Management book in College that can help lecturers and students as well as archivists in managing dynamic archives in College.

\section{Theoretical Framework}

Office Administration Education Study Program is one of the study programs in the Majoring of Economics that prepares students to become prospective teachers in vocational high schools in business management or to become administrative staff in both government and private institute. As a prospective teacher of a vocational high school business must 
master a variety of office work which includes managing dynamic archives, as well as when graduates work as administrative staff in government and private intitute.

The Office Administration Education Study Program equips students with skills in managing dynamic archives. Dynamic archive management is the process of controlling archives since archives were created, used, maintained and depreciated or destroyed [9]. Each stage in dynamic archive management uses a different mix.

The initial stage of the life process of the archive is the stage of creating the archive, at this stage the archive was created or made, then used as a medium for delivering information as a basis for planning, organizing, taking intelligence, monitoring and so on. Creation of archives properly must follow the Guidelines for Official Manuscript (TND) used in every government and private institute as well as in Medan State University. But in reality students or employees have never known much less let alone use TND in the process of creating an archive. The stage of archive creation is carried out through the categorization, registration, and distribution of archive activities. In connection with the creation of archives, required Official Manuscript in the environment of the creator of the archive [10].

The second stage in dynamic archive management is the use and maintenance of archives. At this stage the archive is categorized as a dynamic archive because it is used directly in organizing daily activities. This stage relates to the activity of recovering archives, easy or difficult to rediscover an archive depending on the storage system used. The better the archive storage system, the easier it will be to find the archive again. This archive storage process requires a list of archival qualifications, which include a list of archival qualifications including substantive and facilitative functions.

Dynamic archive is an archive that is still used for planning, decision making, supervision and other purposes. The use of an archive both by individuals and work units must follow the Security Classification System and Dynamic Archive Access System (SKKAAD). This is to prevent the archive from falling into the hands of undue people or institute. Just like the previous understanding of TND, students of Office Administration and Archivists of Medan State University have not been able to understand and use Archive Classification and SKKAAD correctly. Even though the requirements for storing archives must be able to use an archive classification list.

The last stage is the depreciation of the archive, which is the activity of reducing the archive because the frequency of its use has decreased and has no use value anymore [11]. There are three ways to depreciat the archives, namely: (1) transfer files that have a retention of less than ten years from the processing unit to the archival unit or UPT Archive or record center, (2) destroy archives in accordance with applicable regulations or in accordance with the Archive Retention Schedule (JRA), and (3) submit static archives by the archival unit to the archival institution both at the regional and central levels. In the third stage of dynamic archive management requires guidance on Archive Retention Schedules that are created and used for each institute. Students of Office Administration Education and Archivist in Medan State University have also not been able to determine JRA of an archive correctly.

The Curriculum based on Indonesian National Qualifications (KKNI) is a curriculum compiled based on the framework for qualifying the Indonesian human resources qualification that matches, equalizes and integrates the education sector with the training sector and work experience in a work skills recognition scheme that is adapted to the structure in various work sectors. Curriculum based on KKNI is a study program that requires the education system in College to clarify the profile of its graduates, so that it can be adjusted to suitability in the perspective of analyzing the needs of the community, but graduates of Office Administration Education Study Program are not in accordance with KKNI standards. 
The book on Dynamic Archive Management in College is designed according to the needs of practical subjects where the book will include: material covers the basic concepts of Dynamic Archive Management in College and Procedures for storing and recovering documents / files with various filing systems that are designed and still guided by four archive devices, examples of letters and documents that will be stored with various filing systems, examples of the use of TND, KA, JRA, SKKAAD. the practice of saving documents and recovering them with various kinds of filing systems and evaluation instruments, maintaining and destroying files.

\section{Research Method}

This research uses a research and development approach (R\&D), with a combination of qualitative and quantitative research. The method used is descriptive-exportative method to identify various symptoms and root of problems that occur in the study of Dynamic Archive Management and the design of the development of Dynamic Archive Management Book in College.

This research was conducted at the Office Administration Education Study Program, Majoring of Economics, Faculty of Economics Unimed. Willem Iskandar Street Pasar V Medan Estate. The research subjects as a source of quantitative data in this research were lecturers and students who took the Archives Management subject. Lecturers who are the subjects of this research are lecturers who manage the Archives Management subject. While students who are the subjects of this research are students who take the Archives Management subject.

The stages of the research follow the Borg and Gall model [12], R\&D research in education includes ten steps, namely: (1) Tesearch and information colletion, (2) Planning, (3) Develop Preliminary form of Product, (4) Preliminary Field Testing, (5) Main Product Revision, (6) Main Field Testing, (7) Operational Product Revision, (8) Operational Field Testing, (9) Final Product Revision, and (10) Desimination and Implementation. The flow chart of the steps is shown in the following figure:

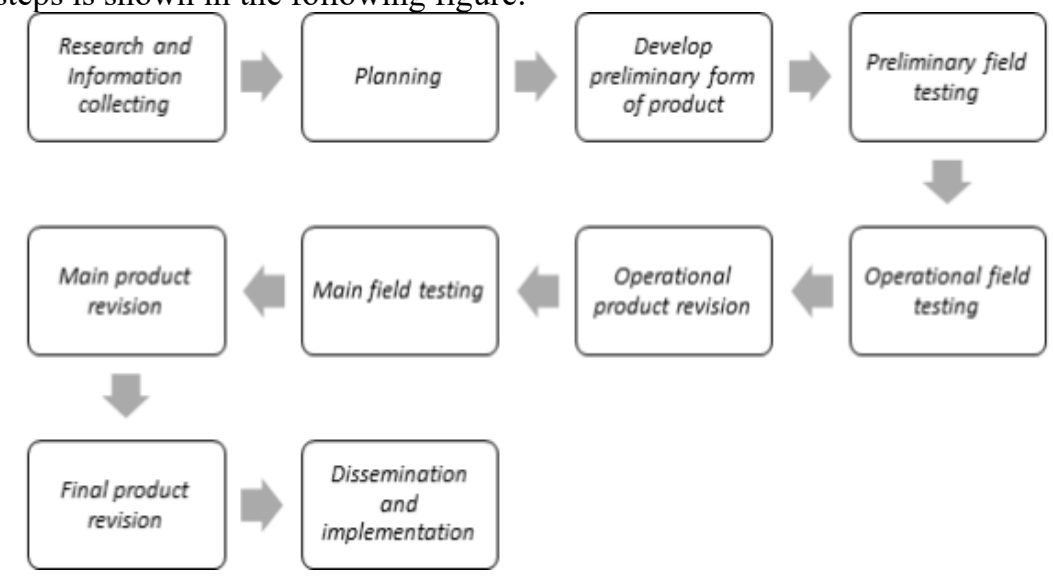

Fig 1. Borg and Gall R\&D Research Steps 
Analysis of the data used in this research is the analysis of qualitative data and quantitative data. To obtain the expected amount of data, data collection instruments are used including: questionnaire, observation sheet. Data in the form of suggestions and input from experts and students are used to improve textbooks that are being developed.

\section{Results and Discussion}

The development of the College Archives Management book follows the Borg and Gall R\&D Research steps with the following steps:

a. Research and information colletion (research and data collection). This first step includes needs, literature studies, literature review, small scale research and required reporting standards. To conduct a needs analysis there are several criteria related to the urgency of product development and product development itself, as well as the availability of competent human resources and sufficient time to develop. The literature study was conducted for a temporary introduction to the College Archives Management book to be developed and this was done to gather research findings and other information related to the development of the planned College Archives Management book. While small-scale research needs to be done so that researchers know a few things about the College Archives Management book that will be developed.

b. Planning. Prepare a research plan, including the abilities needed in conducting research, the formulation of objectives to be achieved with the design research or research steps the possibility of testing in a limited scope.

c. Develop Preliminary Form of Product. This step includes determining the design of College Archive Management books to be developed (hypothetical design), determining the research facilities and infrastructure needed during the research and development process, determining the stages of carrying out design tests in the field and determining the job description of the parties involved in research. This includes developing learning materials, learning processes and evaluation instruments.

d. Preliminary Field Testing. This step is a limited test of the College Archives Management book, which is conducting an initial field test of product design, which is limited, both the substance of the design and the parties involved. The initial field test was conducted with 10 students in order to obtain a decent design, both substance and methodology. During the trial observations, interviews and distribution of questionnaires were held. Data collection by questionnaire and observation which then analyzed. The results of the Questionnaire Analysis are presented in table 1.

Table 1. Results of initial field trials of Higher Education Archive Management books

\begin{tabular}{llcc}
\hline No & \multicolumn{1}{c}{ Rated Aspect } & Average & Category \\
\hline 1 & Display of Archive Management book PT & 3,5 & Very Good \\
2 & The PT Archives Management book makes & 3 & Good
\end{tabular}

learning more enthusiastic 


\begin{tabular}{|c|c|c|c|}
\hline No & Rated Aspect & Average & Category \\
\hline 3 & $\begin{array}{l}\text { PT Archive Management Book makes learning } \\
\text { not bored }\end{array}$ & 2,9 & Good \\
\hline 4 & $\begin{array}{l}\text { The PT Archive Management Book makes it } \\
\text { easy to learn about archives }\end{array}$ & 3,3 & Good \\
\hline 5 & $\begin{array}{l}\text { PT Archive Management Book motivates to } \\
\text { study archival material }\end{array}$ & 3,2 & Good \\
\hline 6 & $\begin{array}{l}\text { The material in the PT Archives Management } \\
\text { book deals with the management of daily } \\
\text { archives }\end{array}$ & 3,3 & Good \\
\hline 7 & $\begin{array}{l}\text { The material in the PT Archives Management } \\
\text { book is easy to understand }\end{array}$ & 3 & Good \\
\hline 8 & $\begin{array}{l}\text { The examples in the PT Archives Management } \\
\text { book are very helpful for understanding } \\
\text { archival material }\end{array}$ & 2,6 & Good \\
\hline 9 & $\begin{array}{l}\text { Shows the order / hierarchy of the text } \\
\text { composition (chapters, subchapters, sub- } \\
\text { chapters) in stages so that it is easy to } \\
\text { understand }\end{array}$ & 2,7 & Good \\
\hline 10 & $\begin{array}{l}\text { The sentences used follow Indonesian sentence } \\
\text { procedures }\end{array}$ & 2,7 & Good \\
\hline 11 & $\begin{array}{l}\text { The sentences and paragraphs used in the PT } \\
\text { Archive Management book are clear and easy } \\
\text { to understand }\end{array}$ & 2,7 & Good \\
\hline 12 & $\begin{array}{l}\text { The language used in the PT Archives } \\
\text { Management book is simple and easy to } \\
\text { understand }\end{array}$ & 2,6 & Good \\
\hline 13 & The typeface used is simple and easy to read & 2,6 & Good \\
\hline
\end{tabular}

a. Main Product Revision. This step is an improvement of the model or design based on limited field testing. Improvement of the initial product will be carried out after a limited field trial. At the stage of perfecting the College Archive Management book, the results of this initial field trial, were carried out more by a qualitative approach. Improvements made include: clarifying the steps in managing archives, adding examples of managing archives, adding images of materials and equipment used in managing archives, choosing fonts that are easier to read.

b. Main Field Testing. The revised College Archive management book is then used in the main product field test involving 20 students. This step is a further Archive Management book test, including testing the effectiveness of product design, testing the effectiveness of the design. The results of this test are effective design in terms of substance and methodology. Data collection by questionnaire and observation which then analyzed. The results of the Questionnaire Analysis are presented in table 2.

Table 2. Results of field trials of main products

\begin{tabular}{llcc}
\hline No & \multicolumn{1}{c}{ Rated Aspect } & Average & Category \\
\hline 1 & Display of Archive Management book PT & 3,5 & Very Good \\
2 & $\begin{array}{l}\text { The PT Archives Management book makes } \\
\text { learning more enthusiastic }\end{array}$ & 3,35 & Good \\
3 & $\begin{array}{l}\text { PT Archive Management Book makes learning } \\
\text { not bored }\end{array}$ & 3,15 & Good \\
4 & The PT Archive Management Book makes it easy & 3,55 & Very Good
\end{tabular}




\begin{tabular}{|c|c|c|c|}
\hline No & Rated Aspect & Average & Category \\
\hline & to learn about archives & & \\
\hline 5 & $\begin{array}{l}\text { PT Archive Management Book motivates to } \\
\text { study archival material }\end{array}$ & 3,6 & Very Good \\
\hline 6 & $\begin{array}{l}\text { The material in the PT Archives Management } \\
\text { book deals with the management of daily } \\
\text { archives }\end{array}$ & 3,6 & Very Good \\
\hline 7 & $\begin{array}{l}\text { The material in the PT Archives Management } \\
\text { book is easy to understand }\end{array}$ & 3,5 & Very Good \\
\hline 8 & $\begin{array}{l}\text { The examples in the PT Archives Management } \\
\text { book are very helpful for understanding archival } \\
\text { material }\end{array}$ & 3 & Good \\
\hline 9 & $\begin{array}{l}\text { Shows the order / hierarchy of the text } \\
\text { composition (chapters, subchapters, sub-chapters) } \\
\text { in stages so that it is easy to understand }\end{array}$ & 3 & Good \\
\hline 10 & $\begin{array}{l}\text { The sentences used follow Indonesian sentence } \\
\text { procedures }\end{array}$ & 3,05 & Good \\
\hline 11 & $\begin{array}{l}\text { The sentences and paragraphs used in the PT } \\
\text { Archive Management book are clear and easy to } \\
\text { understand }\end{array}$ & 3,1 & Good \\
\hline 12 & $\begin{array}{l}\text { The language used in the PT Archives } \\
\text { Management book is simple and easy to } \\
\text { understand }\end{array}$ & 3 & Good \\
\hline 13 & The typeface used is simple and easy to read & 3,5 & Very Good \\
\hline
\end{tabular}

a. Operational Product Revision. This step is the product improvement of the field test results based on the input and main field test results. So this improvement is the second improvement after a wider field test than the first field test. In accordance with the respondents' input to make it easier to determine Archive Classification and determine Archive Retention Schedules, an attachment to Archive Classification and Archive Retention Schedule was added to the draft book.

b. Operational Field Test (Large scale field trial / due diligence). This step was taken to involve 30 third semester students taken in the Dynamic Archives Management subject. Large-scale field trials are conducted to test the compatibility and adaptability of product designs, and the compatibility and adaptability trials of designs support potential product users. Field test results consist of models that have been applied, both in terms of substance and applied.

c. Final Product Revision. This step is a improvement of the product being developed. Improvement of the final product is deemed necessary for more accurate products being developed. At this stage a product whose level of effectiveness can be accounted for has been obtained. The final product improvement has a reliable "generalization" value. Improvement is based on input or the results of the feasibility test in a wide scale.

The results of research on the development of College Archive Management books are books that will be used for archival learning and college archive management. The College Archives Management book presents material: 1) Understanding the basic concepts of College Archives Management, 2) Using the Official Script Management, 3) Using Archive Classification, 4) Using the Archive Retention Schedule, 5) Conducting Active Archive Management, 6) Conducting Archive Management Inactive, 7) Conduct Static Archive Management, 8) Conduct Vital Archive Management, 9) Conduct Archival Depreciation 
The Learning Media that was designed was the Archive Management video in the Archive Technical Services Unit of Medan State University. Learning media that are designed to describe the steps in managing college archives at Medan State University.

The learning tools designed include Semester Learning Plans, Evaluation Instruments including questions and assessment rubrics based on the Indonesian National Qualification Framework.

\section{Conclusions}

This College Archives Management book is interesting and needs to be developed so that it can be used in archival learning and archive management in University. Based on the results of large-scale field trials involving 30 students, it is known that learning by using the College Archive Management book designed can improve student learning outcomes.

This College Archives Management book can be used as a learning resource for students in studying Archive Management, it can also be used by archivists and archival managers in managing state and private university archives.

The design of teaching and learning activities and learning media that are designed can be used to facilitate understanding of college archive management materials.

\section{References}

[1] Best, D. P, The future of information management. Records Management Journal. https://doi.org/10/1108/09565691011039834 (2010).

[2] Penn, T. The ordinariness of the archive. History of the Human Sciences. https://dsi,irg/10.4324/9781315245140 (2017).

[3] Kepala Arsip Nasional Republik Indonesia (ANRI) Regulation number 24 year of 2011, about Guidelines for Organizing Archives in Higher Education.

[4] Willis, A. Corporate governance and management of information and record. Records management Journal. https://doi/org/10.1108/09565690510614238 (2015).

[5] McDonald,J. Records management and data management: Closing the gap. Records management Journal. https://doi.org/10.1108/095656910111039825 (2010).

[6] RI Government Regulation No. 28 year of 2012 about Implementation of Law Number 43 of 2009 concerning Archiving.

[7] Azmi, Reformasi Birokrasi dalam Perspektif Penyelenggaran Kearsipan. Jurnal Kearsipan, vol.4, no 1, p.1-34 http://www.anri.go.id/assets/download/vol4 jurnal anri 12 2015.pdf (2016).

[8] Teknologi, dan Pendidikan Tinggi Republik Indonesia Number 23 of 2018, concerning Archive Classification, Archive Retention Schedule, and Security Classification System and Dynamic Archive Access at Kemenristekdikti, (2018).

[9] Sugiarto dan Teguh Wahyono. Manajemen Kearsipan Elektronik. Yogyakarta: Gava Medika (2014).

[10] Muhidin, Sambas Ali dan Henri Winata. Manajemen Kearsipan untuk Organisasi Publik, Bisnis, Sosial, Politik, dan Kemansyarakatan. Bandung: Pustaka Setia (2016).

[12] Barthos, Basir. Manajemen Kearsipan. Jakarta: Gramedia Pustaka (2014).

[13] Borg, W.R and Gall, M.D. Educational Research: An Introduction $4^{\text {th }}$ Edition. London: Longman (2003). 